\title{
The botanical explorations of Thomas Coulter in Mexico and California.
}

\author{
FREDERICK V. COVILLE.
}

WITH PLATE XXXV.

Among the botanical explorers in North America during the first half of the present century was Dr. Thomas Coulter, an Irish botanist, whose collections were the basis of important contributions to the descriptive botany of Mexico and California, but the details of whose life and route of travel are known only from the most fragmentary recoras. As illustrating the haze of uncertainty that surrounds the collections of Coulter I may cite the case of Berginia virgata. This acanthaceous genus with its single species was founded on Coulter's no. $603^{1}$, accreditcd in the original description as "Californiæ incola." Later Dr. Asa Gray said of the plant, "not since met with; more probably collected in Arizona or within the borders of Mexico;" 2 and still later "probably Arizona: not since found." 3 In our inability, therefore, to ascertain an original station, the location of one of our monotypic genera was unknown for fifty years after it was first collected and finally when found in Sonora in I 884 by Mr. C. G. Pringle it was re-described by Dr. Gray as a new genus and species, Pringleophytum lanceolatum. ${ }^{4}$ Had Berginia not become an essentially lost genus, from a lack of knowledge of the type locality, all this difficulty would doubtless have been avoided.

Thomas Coulter was born in the year I 793 near Dundalk, County Louth, Ireland, 5 and showed an early liking for out-

${ }^{1}$ Harv.; Benth. \& Hook. Gen. Pl. 2: 1096. I 876.

${ }^{2}$ Gray, Bot. Cal. 1: 588. 1876 .

${ }^{3}$ Gray, Syn. Fl. 2': 327 . 1878 .

4 Gray, Proc. Amer. Acad. 20: 292, 293. 1895.

${ }^{5}$ See Proc. Roy. Irish Acad. 2: 553-57. 1844. A five-page biographical sketch of Coulter is here given by his most intimate friend, the astronomer and physicist, Dr. John Thomas Romney Robinson, who invented the common cup anemometer and for whom Professor Harvey named the papaveraceous genus Romneya. This sketch seems to have escaped the attention of botanists, for neither Wittstein (Etymologisch-botanisches Handwörterbuch 233. 1856, [ed. 2]), nor Pritzel (Thesaurus Literaturæ Botanicæ 70. 1872), nor Hemsley (Biologia Centrali-Americana, Botany 4: 125. 1887), nor Britten and Boulger (Journal of Botany 26: 244. 1888) give either the place or the date of Coulter's birth. 
door sports and natural history. He was prepared for college by Dr. William Neilson, author of a formerly well known Irish grammar, through whom he acquired an interest in the antiquities of Ireland. His education was continued at Dublin University where he showed marked proficiency in the mechanical and physical sciences and attracted particular attention for his knowledge of entomology and botany. His local collections of insects and mosses even at this time were large and valuable. In I8I7 he was graduated with the degree B. A., and continuing his graduate work he took the degrees M. A. and M. B. in I820. ${ }^{6}$ He had already spent one or two summers in Paris, making there extensive collections of the plants of the Jardin des Plantes. After leaving the University he went to Geneva, where under the direction of DeCandoile he continued his botanical studies. $\mathrm{He}$ made a large collection of continental plants, compared them critically with DeCandolle's collections, and afterward, beginning in the spring of 1823 , deyoted himself to the elaboration of a monographic essay on the Dipsacex. The results of his investigations were published later in the year in his Mémoire sur les Dipsacées, an excellent work which, together with additional manuscript notes prepared in part at least at the herbarium of Delessert in Paris and communicated to DeCandolle in I 824, formed the basis for the elaboration of the Dipsaceæ published in the Prodromus in 1830.7 The memoir was republished in 1824 by the Société de Physique et d'Histoire Naturelle de Genève. At the time of publication of his Dipsaceæ Coulter was already a Doctor of Medicine and a member of the Royal Irish Academy. This membership, which began March I6, I8I9, he retained, as may be seen from the lists of members occasionally published in the Academy's Transactions, until his death.

In the year I 823 the Brazilian genus Coulteria of the Leguminosæ, now treated as a section of Caesalpinia, was named in honor of Dr. Coulter, ${ }^{8}$ and the statement made that he was about to undertake an exploration in Chile. Returning to Ireland in 1824 , he made preliminary arrangements for a trip to Argentina, Chile, Bolivia, California, and Mexico. $\mathrm{He}$ subsequently decided, however, to begin his travels with the

'These dates. have been kindly furnished by Professor E. Percival Wright from the records of Dublin University.

${ }^{7}$ See A. P. DeCandolle, Prodr. 4: 643. 1830.

${ }^{8}$ H.B.K. Nov. Gen. \& Sp. 6: 328. 1823 . 
last named country, accepting a position as medical attendant, or, as we should say, physician, of the Real del Monte Mining Company, under a three years' contract.

Coulter sailed from England in August, I824, and doubtless reached Mexico in the same year, but the recorded details of his work there are very meager indeed. In a chronometric table given by Coulter in his Notes on Upper California are named certain localities in Mexico at which he took observations. The year unfortunately is not given, but the localities and partial dates are as follows:

Zimapan [state of Hidalgo] . . . . . April 8 to 15.

Mexico [city] . . . . . . . April 22 to 29.

R. D. Monte [Real del Monte, an old mining town in the state of Hidalgo, situated in the mountains about fifty miles northeast of the city of Mexico]. . . . . . . . . . May I to I4.

In a meteorological table in the same paper Coulter cites from his journal certain temperature observations made, presumably by himself, at Veta Grande, a mining pueblo not more than ten miles north of the city of Zacatecas, in the state of the same name, from December 2, 1825, through the month of January following. Coulter, by reason of the desertion of some of his company's employees, was compelled to act, for more than a year, as superintendent of this important, and in his hands productive, mine.

After the termination of his engagement with the mining company, Coulter was located for a time at Hermosillo, a large town in the state of Sonora, on the river of the same name. His reference to this place is as follows:

"It [sometimes] freezes even to the south of Pitis [Hermosillo], ${ }^{9}$ in lat. N. $29^{\circ}$; and in the winter of $1829-30$, it froze in Pitis every night for nearly two months. On the 12 th of December, on arriving at San Jose, a few leagues from Pitis [probably San Jose de Pimas, an old mining pueblo on the Rio Matare about sixty miles southeastward from Hermosillo], I found the thermometer at $I 8^{\circ} \mathrm{Fahr}$., at $8 \mathrm{~h}$. P. M. On the 13 th, it stood in the shade below $32^{\circ}$ all the day, at night sinking even to $18^{\circ}$. This, however, appears to occur very rarely." 10

${ }^{9}$ On the maps of Humboldt and others to as late a date as 1840 this town was given variously as Pitic, Petic, and Pitit, but from the decade following that year the name Hermosillo appears on all the maps, though in Lippincott's Gazetteer these two names are not identified as belonging to the same town.

10 Thomas Cculter, Notes on Upper California 69. 1835. 
It is probable that Coulter passed through Guaymas on his way to or from Hermosillo, for two rare plants known only from the coastal flora at Guaymas, Acacia zvillardiana (Prosopis heterophylla) and Perityle leptoglossa, were in Coulter's collections, and many other species first brought to light by him have since been collected at that point. ${ }^{11}$ It is known also from localities given by Hemsley in the Biologia Centrali-Americana for various plants collected by Coulter that he visited Jalapa, Guadalajara, Bolaños, Tepic, San Blas, and Mázatlan, all of which are well known as old mining towns or as sea-ports.

The first recorded news from Coulter, after his departure for Mexico, is furnished by DeCandolle, who in the year 1828 received from him a collection of fifty-seven species of living Cactaceæ, forty-seven of which DeCandolle immediately published as new, with no reference, however, to Coulter's movements. ${ }^{2}$ Additional new species from this collection and remarks nn his former descriptions were published by DeCandolle as a memoir six years later. ${ }^{13}$ A similar collection of Cactaceæ, consisting of seventy species and varieties, was sent by Coulter to Trinity College, Dublin, for the botanical garden there in charge of $\mathrm{Mr}$. James $\mathrm{T}$. Mackay.

Of Coulter's work in California, after the termination of his travels in Mexico, we have much more satisfactory records. His headquarters were at Monterey. He reached that port, undoubtedly by sea and probably from San Blas, Jalisco, on the Mexican coast, ${ }^{4}$ apparently in November, 1831; for David Douglas, writing to Dr. Hooker from Monterey under date of November 23rd in that year, stated that Dr. Coulter had arrived since he began the letter. These two botanists evidently worked together, to the great delight of Douglas, during the winter of $183 \mathbf{I}-2$ and the following spring, Douglas finally sailing from Monterey to the Sandwich Islands and Coulter setting out on his trip to Arizona. ${ }^{15}$

As Coulter's journey from Monterey to the mouth of the Gila is the one with which the botanists of our own country are mainly concerned, it has seemed desirable to record in

${ }^{1}$ See Wats. Proc. Amer. Acad. 24: 30-82. 1889.

12 See note on DeCandolle's $R \div$ vue de la famille des Cactées, below.

13 See note on DeCandolle's Mémoire sur quelques nouvelles espèces de Cactées, below.

14C. C. Parry, Early Botanical Explorers of the Pacific Coast 6. (Reprinted from the Overland Monthly for October, 1883.)

15 W. J. Hooker, Comp. Bot. Mag. 2: $151-153$. 1836 . 
some accessible place the details of his route. I therefore append suitable extracts from his Notes on Upper California and present also a photolithographic reproduction of a portion of the map issued with his paper.

(Plate $X X X V$.

[p. 6o] "It will not be necessary to enter, at present, into much detail of my journeys in the country, of which the principal was that from Monterey to the junction of the Rios Colorado and Gila.

[p. 63] "It would occupy too much time to go at present into any great detail of my travelling inland. I am tempted, however, to say a few words of the journey of which the principal [geographical] observations are [p. 64] given above, as it was the most interesting, the longest, and by far the most laborious of those I made in California.

"The rainy season of 1832 ended late in February, which is rather after the usual time, and I started so soon as the country was passable, which it is not at all during the rains, nor for some time afterwards. The rivers, which in the dry season are mere beds of sand, are quite impassable when swollen; and even for some weeks after they have fallen low, the danger and difficulty of crossing some of them, on horseback, are very considerable. If these streams carried down only sand, they might be passed as soon as the rapidity of the current was so far abated that a horse could stand; but the sand comes down mixed with a vast quantity of mud, which settles together with it; so that even when the stream becomes so low that a small animal can walk across, a horse or a man cannot. It is not until the mud is gradually washed out of the surface of the deposit that this becomes possible. We have then a bed of hard sand resting upon one of semifluid mud and sand; and it is very difficult to say when and where it is safe to attempt the passage. On this occasion I had to pass the Guadalupe [now the Santa Maria river, between San Luis Obispo and Santa Barbara counties], in this state, between San Luis Obispo and La Purissima; ${ }^{16}$ and it was only after long search that I found a place where a bear had passed, and trusting to his sagacity I followed his steps. The stream was broad, very shallow, and the bed of clear sand on the surface of the deposit must have been very thin, for it swagged under foot like the surface of a quagmire. A body of troops which passed this way some days before, though on a most urgent affair, was obliged to wait for ten days to allow the sand to settle.

"From Monterey southward the road runs through a series of narrow ravines, as far as San Luis Obispo; but about Santa Ynez, south of San Luis, and again in the neighborhood of Santa Barbara, it runs on, or close by the beach; whence, southward, it keeps chiefly along the west foot of the mountains, separated from the sea by low sand-hills, in some places of considerable breadth, as at San Gabriel, where they are almost twelve leagues broad. The best way to the Colorado, in the dry season, is to follow the coast road as far as San Luis Rey, and

${ }^{18}$ The mission of La Purissima Concepcion, originally situated on the south bank of the Santa Inez river, about half way between Santa Inez and the sea, but in 1813-15 moved to a new site about two miles northeastward on the old wagon road between San Luis Obispo and Santa Inez. 
thence ascend the Pala stream [San Luis Rey river], which runs in a very narrow ravine behind the maritime ridge, crossing the summit level between its head and that of the small stream of San Felipe [a stream heading in Warner pass, San Diego county], which runs southeastward till it reaches the border of the sand plain [the Colorado desert] at Carizal, ${ }^{17}$ where it sinks; though its course across the plain, when swollen, which it rarely is, is marked by a dry channel, in many points of which a little water, usually very bad, is to be had by deep digging.

"There is not much difficulty in any part of the journey up to this point,- - the Carizal; but from hence across the plain, which is here about one hundred miles broad, and totally destitute of [p. 657 pasture, cattle suffer extremely. It is always possible to carry water enough for a party of men; but horses and mules must pass the first two days absolutely without water or food,-and even then get only brine at the point called the Aqua Sola [probably the 'lagoons' at Alamo Mocho of the Pacific railroad reports and recent maps], from its being the only pond on the plain. When I passed, the water I found at this place was so strong that it purged both men and cattle. There is here some rush and reed which mules will eat, though horses usually refuse them.

"From hence there is still another day's journey to the Rio Colorado. After passing the river the same difficulties continue for seven days farther, on the Sonora road, as far as Alta; but this part of the journey, from its greater length, it is extremely imprudent to attempt without a proper guide. ${ }^{18}$ The only water to be had is found in the ravines, frequently at some distance from the road, in excavations called Tinajas, made by the Indians, who were formerly much more numerous in this neighborhood than they are at present.

[p. 68] "I shall not at present go into any examination of the vegetation of California, though this, as well as its fauna, is well worthy of the most attentive consideration.

[p. 70] " 1 am sorry to be obliged to content myself with offering the Society so desultory and imperfect a sketch as this; but I have many claims on my time, the most urgent of which is the preparation of a work in some detail on the entire subject of California. Whatever is here defective will there, I hope, be found supplied." 1 o

From certain chronometric tables, given by Coulter on page $6 \mathrm{I}$, in connection with his determinations of longitude, have been taken the following dates in his journey from Monterey to the mouth of the Gila in Arizona, all in the year 1832 .

17. According to Coulter's narrative, the Carizal is the sink of San Felipe creek. According to his map, however, it is on Carrizo creek, the next stream to the south, thus corresponcing to the place known as Carrizo in the Pacific railroad reports and on recent maps. Carinal on Coulter's map is a misprint.

${ }^{18} \mathrm{It}$ is clear from the dates of his itinerary and from statements in i.is article that Coulter did not at this time go on to Sonora but that he is here merely describing the road which might be followed into that country.

${ }^{10}$ See page 525 regarding the subsequent loss of his manuscripts. 
Monterey . . . . . . . January 22 to March 20.

Santa Barbara . . . . . . . . . . . April 6.

San Gabriel . . . . . . . . . . . . April 23.

La Pala [Pala, San Diego county] . . . . . April 30.

Ford [of the Colorado river, at or near the site of the

present town of Yuma] . . . . May 8 to I 7.

La Pala

San Gabricl

Santa Barbara

Monterey

May 27.

June I 5 .

July 5 to 7 .

After further collecting in California, apparently always in the vicinity of Monterey, Coulter returned to Europe by way of Mexico, in the year I 834, bringing with him his collection of over 50,000 specimens, probably representing between I, 500 and 2,000 species, besides a collection of nearly I,000 woods, botanical manuscripts, journal, and additional materials for a personal narrative. All these manuscripts were in some unaccountable way lost in transport between L.ondon and Dublin. Suffering from this loss, and broken in health from the hardships of his travels, he devoted himself thereafter quietly and unremittingly to the arrangement of his herbarium, which, with its total of about I 50,000 specimens, became the property of Trinity College, he himself being appointed keeper, or curator. At the time of his death, in I 843, he had completed the arrangement of the European plants and had begun on his American collections.

The collections of Cactaceæ sent to De Candolle seem to have contained the only ones of Coulter's plants that reached an avenue of publication previous to his death, with the exception of five new Californian pines described in the paper by David Don, and the Cupressus coulteri of Forbes. $^{20}$ But Professor W. H. Harvey, upon his appointment as Coulter's successor, in $1844,{ }^{21}$ proceeded with the arrangement of the Californian and Mexican plants, ${ }^{2} 2$ issued three short papers ${ }^{2} \mathbf{3}$ on them, and, apparently in the years 1846 to 1848 , distributed the greater part of the duplicates, the first set going to Kew and others to Dr. Asa Gray and Dr. John Torrey in America. The specimens were sent out under more than I,700 numbers, unfortunately arranged systematically instead of chronologically.

20 See bibliography and list of species below.

21 Gray, Amer. Journ. Sci. II. 42: 274. 1866.

22 [Anon.] Memoir of W. H. Harvey 147, 156. 1869.

23 See bibliography, below. 
[December,

I give herewith the titles of the special papers based on Coulter's collections, together with his own two publications, all chronologically arranged.

Coulter, Thomas.

Memoire sur les Dipsacées. pp. 49. pl. 2. $4^{0}$. Genève, 1823.

Reprinted in Mém. Soc. Phys. de Genève 22: 13-60. pl. 2. 1824. The type pages in the two works are identical, with the exception of the page numbers and the signature marks. Page 44 of the original, immediately preceding the index, is blank, but in the reprint is filled by runnıng the succeeding matter one page backward.

A revision of the family, preceded by a brief statement of the circum. stances under which the work was undertaken and an elaborate morphological introduction.

DeCandolle, A. P.

Revue de la famille des Cactées. Mém. Mus. d'Hist. Nat. de Paris 17: I-I 19. 1828 .

Pages 107 to 119 consist of a postscript, presented to the Société Helvetique des Sciences Naturelles at Lausanne July 22, 1828, based on a collection of fifty-seven species of living Mexican Cactaceæ received from Thomas Coulter while the paper was in press, and clearly the first lot of Coulter's Cactaceæ that came into De Candolle's hands. Fortv-seven species were described as new, 25 Mamillariæ, 5 Echinocacti, 10 Cerei, and 7 Opuntiæ. Unfortunately no more specific locality than "Mexico" was given for any of the species, nor does the paper include any other reference to Coulter's collections, location, or movements.

DeCandolle, A. P.

Mémoire sur quelques espèces de Cactées nouvelles ou peu connues. pp. 27. pl. 12. $4^{\circ}$. Paris, 1834 .

The half-title of his work is "Mémoire sur quelques nouvelies espèces de Cactées, et principalement sur celles envoyées du Mexique par le Docteur Coulter." It contains descriptions of three new species, two Mamillariæ and one Echinocactus, with critical notes on twenty-four others. Almost all this new matter is based on cultivated specimens from Coulter's first consignment in 1828 .

Coulter, Thomas.

Notes on Upper California. Journ. Roy. Geog. Soc. Lond. 5: 59-70. 1835. With map.

A geographic account of California with a brief description and map of his route in 1832 from Monterey to the mouth of the Gila and return.

Don, Davin.

Descriptions of five new species of the genus Pinus, discovered by Dr. Coulter in California. Trans. Linn. Soc. Lond. 17: 439-444. $18,36$.

Describes Pinus coulteri, $P$. muricata, $P$. raliata, $P$. tulicrculnta and $P$. [Abies] bracteata, and.gives a brief reference to Coulter's work in California.

HARVEY, W. H.

Description of a new genus of Papaveraceæ. detected by the late Dr. Coulter, in California. Lond. Journ. Bot. 4: 73-76. pl. 3. 1845.

A description of the genus Romneya and its single species, $\mathcal{R}$. coulteri.

HaRvey, W. H.

Characters of two new genera of Cruciferæ, discovered by the late Dr. Coulter, in California. Lond. Journ. Bot. 4: $76 \cdot 78$ pl. 4. 5. 1845 .

Describes the genera Lyrocarpa Hook. \& Harv. and Dithyrea Harv. with the species $L$. coulteri Hook. \& Harv. and D. californica Harv. respectively. HARVEY, W. H.

Description of a new genus of Hydrophyllaceæ, from California. Lond. Journ. Bot. 5: 31I-12. I846.

The genus Whitlavia described, with its two species, W. grandiflor $W$. minor, both collected by Thomas Coulter. 
The descriptions of most of Coulter's new species have come into the literature of botany irregularly and incidentally in various reports and monographs prepared at the great herbaria which received his collections, so that the complete collation of them would be a matter of great difficulty and probably not worth the effort. As indicative, however, of some of the avenues of publication, I append a list, chronologically arranged, of most of the species that bear his name, together with a few critical notes on other species regarding which mistakes appear to have been made.

Pinus coulteri Don, Trans. Linn. Sxc. Lond. 17: 440. 1836.

"Habitat in California, in montibus Sanctæ Luciæ, alt. 3.000-4,000 ped. Coulter."

Cupresisus ciulteri Forbes, Pinet. Woburn. 190. 1839.

Publication not seen.

Romneva coulteri Harv Lond. Journ. Bot. 4: 75. pl. 3. 1845.

"In California boreali legit \% Couller, 1832." Known only from the coastward side of the San Jacinto mountains in San Diego county.

Lyrocarpa coulteri Ho ik. \& Harv. Lond. Journ. Bot. 4: 76. 1845.

"In California legit $T$. Coulter, I832. (No. 40.)" Since collected only in Sonora and Lower California.

Prosopis heterophrllix Benth. Lond Journ. Bot. 5: 82, 1846.

"Sonora Alta, in Sonora, Mexico." Now called Acacia zuillardiana, and known only from Guaymas.

Prosopis rubescens Benth. Lond. Journ Bot. 5: 82 I 846.

"California between San Miguel [in the northern part of San Luis Obispo county] and Monterey." The plant does not occur in the region named, but doubtless came from the Colorado Desert, where it is a common and characteristic tree. Coulter passed through San Miguel, although he did not give the place a name on his map, on his trip from Monterey to the mouth of the Gila.

Antirrhinum coulterianum Benth.; A. DC. Prodr. 10: 592. I846.

"In California (Coulter)." "Now known from the coastal side of the San Bernardino-San Jacinto mountain system of southern California.

Linum coulterianum Planch. Lond. Journ. Bot. 7: 498. 1848.

"In regni Mexicani ditione Zimapan, Dir. Coislter, no 758, in herb. Hook. a cl. Harvey comm." Considered by Mr. Hemsley a variety of Linum schiedernum $\mathrm{Ch}$. \& Schl.

Dalea mollis Benth. Pl. Hartw. 306. I 848 .

"In vicinibus Monterey [California] legit Coulter." This plant has not been rediscovered at Monterey, and as it is now known to be a species characteristic of the California-Arizona desert region the locality given by Bentham should be treated, as intimated by Dr. Sereno Watson, in the Botany of California, as incorrect. It w.is undoubtedly collected by Coulter in the Colorado Desert on his trip from Monterey to the mouth of the Gila.

Astragalus coulteri Benth. Pl. Hartw. 307. 1848 .

"Juxta Monterey [California] legit Coulter." A species of the Colorado Desert, California, not known in the coastal region and undoubtedly attributed to that district by mistake.

Eunanus coulteri Harv. \& Gray; Benth. Pl. Hartw. 329. 1849.

"In valle Sacramento." The description was drawn by Bentham from a specimen collected by Hartweg as above, but the name was borrowed 
from unpublished manuscript of Harvey and Gray, based undoubtedly on one of Coulter's Californian plants.

Obione coulteri Moq. DC. Prodr. 132: I13. 1849.

"In California (Coulter! n. 687)." Supposed to be a plant of San Diego county, now referred to Atriplex, but not yet satisfactorily identified.

Pectis coulteri Harv. \& Gray; Gray, Pl. Fendl. 62. 1849.

"California, Coulter (no. 330)." A.desert species, undoubtedly collected on Coulter's trip to the mouth of the Gila.

Psilactis coulteri Gray, P1. Fendl. 72. 1849.

"Mexico, Coulter, no. 295." Known now as a widely distributed desert species of southeastern California, Arizona, and northwestern Mexico.

Perityle leptoglossa Harv. \& Gray; Gray. Pl. Fendl. 77. 1849.

From "Coulter's Californian collection." In Gray's Synoptical Flora 12: 321 . 1884, the locality is given as "probably Arizona." It has been recollected at Guaymas by Dr. Edward Palmer, and Mr. Rose believes that the original specimens were collected in this region, not in California.

Cirsizum coulteri Hurv. \& Gray; Gray, Pl. Fendl. IIO. I849.

"Calıfornia, Coulter." 'Referred later by Dr. Gray to Cnicus occidentalis which is principally a coastal species.

Malacothrix coulteri Harv. \& Gray; Gray, Pl. Fendl. II3. I849.

"California, Coulter.". A species principally confined to the desert region. In the original description the name of the species is cited from "Harv. \& Gray, Pl. Coult. ined." indicating that a joint work on Coulter's collections was contemplated by Dr. Gray and Professor Harvey.

Oserya coulteriana Tulasne, Ann. Sci. Nat. Bot. III. 11: 106. 1849.

"Nova Hispania.-(Coulter, no. I,394.)"

Tauschia coulleri Gray \& Harv.; Gray, Pl Lindh. 2: 211 . 1850.

No. 121 of Coulter's Mexican collection. Now Arracacia coulteri (Gray

\& Harv.) Coult. \& Rose.

Menodora coulteri A. Gray, Amer. Journ. Sci. ser. II. 14: 44. 1852.

"'Mexico, Coulter (no. 938)."

Cleomella coulteri Harvey; Torr. in Gray, Pl. Wright. I: I2. I852.

Type locality not given. A nomen nudum for a plant now referred to Wislizenia refracta Engelm.

Kosteletzkya coulteri Gray, P1. Wright. I: 23. r. $5_{52}$.

"Sonora Alta, Northern Mexico, Coulter (no. 804)."

Hibiscus coulteri Harv.; Gray, Pl. Wright. I: 23 . 1852.

"Zimapan, Mexico, Coulter (809)." Description based also on the specimens of Wright and Gregg.

Acacia coulteri Benth.; Gray, P1. Wright. I: 66 . 1852.

"(Zimapan, Mexico, Coulter; without any number.) Uplands of the

Leona river, Western Texas [Wright]."

Bolanosa coulteri Gray, Pl. Wright. I; 82. 1852 .

"Bolanos, Northern Mexico, Coulter."

Brickellia coulteri Gray, Pl. Wright. I: 86. I852.

"California, Coulter (no. 293), in herb. Hook." From southern Arizona to adjacent arid portions of interior northern Mexico, probably collected by Coulter near Yuma where it has since been found.

Elaterium coulteri Gray, Pl. Wright. 2: 6r. 1853 .

"Zacatecas, Mexico, Coulter, no. 5I." This is Echinocystis coulteri (Gray) Cogn.

Tetraclea coulteri Gray, Amer. Journ. Sci. II. 16: 98. I853.

"Mexico, Dr. Coulter (no. I, I72 in coll.).- Prairies of San Felipe and Live Oak creeks, Texas, Wright, 1849 (no. 462); also at Escondido Springs, in the same district, I852. Azufrora, near Saltillo, Mexico, Dr. Gregg (no. 502). Saur de Cieñega, between Conde's Camp and the Chiricahui Mountains, on the borders of New Mexico and Sonora, Wright, I85 I (no. I, 513).", After the description of the genus the specific name is given, with citation of specimens as above but without a diagnosis of the species. 
Guaiacum coulteri Gray, Pl. Thurb. 312. 1854.

"On hills between Rayon and Ures, Sonora; October, 185I [Thurber's collection].-The specimens bear ripe fruit only. They are said by Sir William Hooker to accord with no. 779 of the Mexican collection of the late Dr. Coulter."

Salix coulteri Anders. Oefver. Kongl. Vet. Akad. Förh. 15: I 19. I858.

"In California (Coulter) Hb. Hooker." Now united by Mr. M. S. Bebb with $S$. sitchensis, a species of the coastal region extending from Alaska at least to Santa Barbara, California.

Spigelia coulteriana Benth. Journ. Linn. Soc. Bot. 1: 90. I861.

"In Mexico ad Zimapan, Coulter, n. 962."

Decatropis coulteri Hook. f.; Benth. \& Hook. Sp. Pl. 1: 299. 1862.

"Mexicana." The name $D$. coulteri is cited without description, after the original description of the genus, as the only species.

Orthotrichum coulteri Mitten, Journ. Linn. Soc. 8: 25. I865.

"California, Coulter."

Conyza coulteri Gray, Proc. Amer. Acad. 7: 3551868.

"This is Coulter's no. 285 and 286 and has recently been collected near Fort Mohave [Mohave Desert] by Dr. Cooper."

Berendtia coulteri Gray, Proc. Amer. Acad. 7: 380. I86́8.

"Mexico, no. I334, I335, coll. Coulter, ex herb. Trin. Coll. Dubl."

Peperomia coulteri C. DC. in DC. Prodr 16': 424. 1869.

"In Mexici iprov. Zuinapa (?) [Zimapan] (Coulter n. I400! in h. Kew)." Nama coulleri Gray, Proc. Amer. Acad. 8: 283. 1870.

' 'California' [perhaps Arizona], Coulter, 463. Nazas Valley, Bolson de Mapimi, Chihuahua, Mexico, Gregg." A desert species, not yet re-discovered within the borders of the United States. The brackets are in the original.

Caulanthus coulteri Wats. Bot. King Surv. 27. 1871.

"Southern California." A species not yet satisfactorily known.

Microsplenium coulteri Hook. f.; Benth \& Hook. Gen. Pl. 2: 4. I873.

"In Mexici regione montana a Coultero et a Gal otti (n. 2704) lecta." As in the case of Decatropis the specific name is here cited without description.

Malvastrum coulteri Wats. Proc. Amer. Acad. 11: 125. 1876.

"Collected probably in south-eastern California by Coulter (n. 96) and in the valley of the Gila by Schott, on the Mexican Boundary survey." A species of the desert region, now known as Sphaeralcea coulteri (Wats.) Gray.

Asclepias coulteri Gray, Proc. Amer. Acad. 12: 71 . 1876.

"Mexico, Coulter, coll. no. 983."

Leptoglossis coulteri Gray, Proc. Amer. Acad. 12: 165. 1877.

"Mexico, coll. Coulter, no. 1346." Now Nierembergia coulteri (Gray) Hemsl.

Perezia coulteri Gray, Proc. Amer. Acad. 15: 40. 1879.

"Gravelly slopes, near San Luis [Potosi?] flowering in spring and again

in autumn. No. 547 [Parry and Palmer] in part. This is no. 234 of

Coulter's Mexican collection, from Zimapan."

Sisymbrium coulteri Hemsl. Diag. PI. Nov. 18. 1879.

"Mexico: in regione San Luis Potosi, alt. 6,000-8,000 ped., Parry et

Palmer, 14; sine loco speciali, Coulter, 675."

Exostemma coulteri Hook. f.; Hemsl. Diag. Pl. Nov. 32. 1879.

"Mexico: Zimapan, Coulter 209."

Zaluzania coulteri Hemsl. Diag. P1. Nov. 33. 1879.

"Mexico: Real del Monte, Coulter, 350."

Gutierrezia coulteri Hemsl. Diag. Pl. Nov. 33. 1879.

"Mexico: Zimapan, Coulter, 315."

37-Vol. XX. -No. 12 . 
[December,

Schoenocaulon coulteri Baker, Journ. Linn. Soc. 17: 477. I880.

"Mexico prope Zimapan, Coulter!"

Senkenbergan coulteri Hook. f.; Benth. \& Hook. Gen. Pl. 3: 6. 1880.

Original locality "North Mexico, Sonora Alta (Coulter, 1425). Hb.

Kew", according to Hemsley, Biol. Cent.-Amer. Bot. 3: 5. 1882. Re-

ferred by Dr. Watson to Boerhavia.

Helianthemum coulteri Wats. Proc. Amer. Acad. 17: 323. 1882.

"At Zimapan (743 Coulter) and in the Morales Mountaines, San Luis Potosi (608 Schaffner)."

Calliandra coulteri Wats. Proc. Amer. Acad. 17: 352. I882.

"At Soledad (2129) [Palmer, 1879-80]; collected also by Coulter, without number or locality."

Marsitenia coulteri Hemsl. Biol. Centr.-Amer. Bot. 2: 336 . 1882.

South Mexico, Zimapan (Coulter, 970).

Echites coulteri Wats. Proc. Amer. Acad. 18: 113. 1883.

"In the Sierra Madre, south of Saltillo (805) [Palmer, 1879-80]; 987

Coulter."

Verbesina coulteri Gray, Proc. Amer. Acad. 19: 13. 1883.

"Zimapan, Mexico, Coulter. 341, 369."

Lasthenio glabrata coulteri Gray, Syn. Fl. 1: $: 324.1884$.

"Saline marshes, S. California Coulier (no. 338), Brezver, Cleveland, Pringle."

Carex coulteri Boott; Hemsl. Biol. Centr.-Amer. Bot. 3: 473. I885.

"South Mexico, .Zimapan (Coulter, 1620), Santa Fé, valley of Mexico (Bourgeau, 671)."'

Philadelphuts coulteri Wats., Proc. Amer. Acad. 22: 472. 1887.

"Zimapan (77 Coulter); foothills of the Sierra Madre near Monterey, Mexico (C. S. Sargent, April, 1887)."

It is evident from Coulter's published work and from references to him in the writings of his contemporaries that he was not merely a collector but a botanist, a man of general culture, and an enthusiastic field naturalist and geographer. Regarding his personal characteristics Dr. Romney Robinson ${ }^{24}$ says: "He had every requisite for success among half civilized or savage races: a noble and commanding person; great stature, strength, and dexterity in the use of arms; good temper, courage, and presence of mind: a combination of qualities, which Bruce only, of modern traveliers, possessed in the same degree." Coulter was the first botanist who penetrated the Colorado Desert, ${ }^{25}$ remarkable for the aridity of its climate and the peculiarities of its flora. His collections were very large, and their enumeration, had it been published in a single report, would have formed probably the most valuable contribution to North American botany ever issued. It is hoped that this effort to record an outline of his work will serve to show to some extent the importance of his scientific explorations to the advancement of botany in America.

24 Proc. Roy. Irish Acad. 2: 555. 1844.

${ }^{25}$ See W. H. Brewer in Watson, Bot. Cal. 2: 555. 1880. 


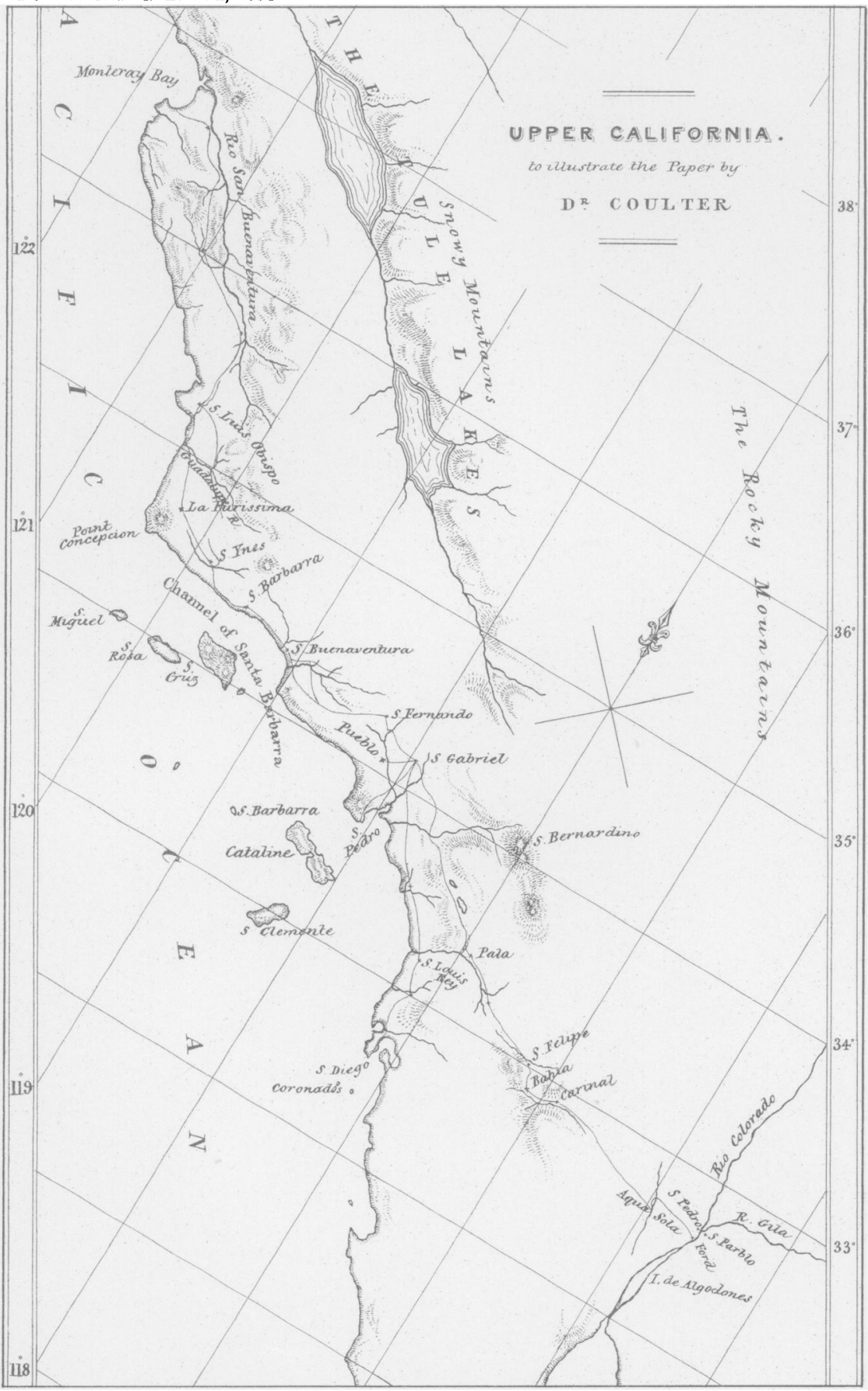

THOMAS COULTER'S ROUTE IN CALIFORNIA.

This content downloaded from 128.143.023.241 on August 12, 2016 02:32:07 AM All use subject to University of Chicago Press Terms and Conditions (http://www.journals.uchicago.edu/t-an 
I earnestly request that any known facts regarding Thomas Coulter not included in this paper be communicated to me. These together with other matter, including the letters of Coulter to Augustin Pyramus and Alphonse DeCandolle, to which through the courtesy of Dr. Casimir DeCandolle I have recently had access, may hereafter be incorporated into a more detailed account of Coulter's labors.

Washington, D. C.

\section{Explanation of Plate XXXV.}

The plate is a photolithographic reproduction, on the original scale, of the principal part of the map, which was itself a lithograph, published with Coulter's "Notes on Upper California." About an inch and a half was cut off the original at the top and bottom, neither portion containing any mark of Coulter's route. 